\title{
Performance-related Pay and Gender Wage Differences
}

Mari Kangasniemi* - Antti Kauhanen ${ }^{* *}$

* Labour Institute for Economic Research, mari.kangasniemi@labour.fi

* ETLA - Elinkeinoelämän Tutkimuslaitos, antti.kauhanen@etla.fi 
Funding from the European Social Fund through the Finnish Ministry of Social Affairs and Health is gratefully acknowledged.

We thank Sami Napari for comments. 


\section{Contents}

$\begin{array}{ll}\text { Abstract } & 2\end{array}$

1 Introduction $\quad 3$

2 Choice of compensation structure and the gender wage gap 4

$\begin{array}{llr}3 & \text { Institutional setting } & 7\end{array}$

$4 \quad$ Data and econometric approach $\quad 8$

4.1 Descriptive statistics $\quad 9$

$\begin{array}{ll}4.2 & \text { The empirical approach } \\ \end{array}$

5 Results 11

5.1 OLS estimation 11

$\begin{array}{ll}5.2 & 12\end{array}$

5.3 Robustness checks: other definitions 14

$\begin{array}{llr}6 & \text { Conclusion } & 16\end{array}$

$\begin{array}{ll}\text { References } & 17\end{array}$

$\begin{array}{lr}\text { Appendix } & 19\end{array}$ 


\section{Abstract}

We study the impact of performance-related pay (PRP) on gender wage differences using Finnish linked employer-employee panel data. Controlling for unobserved person and firm effects, we find that bonuses increase women's earnings slightly less than men's, but the economic significance of the difference is negligible. Piece rates and reward rates, however, tend to increase gender wage differentials. Thus, the nature of a performance related pay plan is important for gauging the impact of PRP on gender wage differentials. A comparison with OLS results shows the importance of controlling for unobserved person and firm effects.

Key words: Gender wage differences, performance-related pay, Person and firm effects, panel data

JEL: J16, J33, M52

\section{Tiivistelmä}

Tämä artikkeli käsittelee kannustinpalkkausta ja sukupuolten palkkaeroja käyttäen yhdistettyä työnantaja-työntekijä aineistoa. Tulokset osoittavat, että tulospalkkaus nostaa naisten palkkoja hieman vähemmän kuin miesten, mutta tämän eron taloudellinen merkitys on mitätön. Urakka ja palkkiopalkat puolestaan kasvattavat sukupuolten palkkaeroja. Kannustinjärjestelmän piirteillä on siis merkitystä niiden vaikutuksille sukupuolten palkkaeroihin. Tulokset osoittavat myös, että yritysten ja henkilöiden heterogeenisuuden huomioiminen on tärkeää, sillä tavallisen pienimmän neliösumman menetelmällä saadut tulokset johtavat harhaisiin johtopäätöksiin.

Asiasanat: Sukupuolten palkkaerot, kannustinpalkkaus, yksilö- ja yritysvaikutukset, paneelidata 


\section{Introduction}

Performance-related pay (PRP) systems have become increasingly popular, and their productivity and wage effects have been studied widely (e.g. 1999, Lazear 2000, Pekkarinen and Riddell 2008). However, the impact of PRP systems on gender differences in wages has received very little attention, and the results from existing studies are mixed.

As a particular form of PRP, piece rates have received the most attention in this scant literature. Jirjahn and Stephan (2004) used cross-sectional data on blue-collar employees to study gender differences in time-wage and piece-rate regimes. The main idea is that gender discrimination is more difficult to practice in the piece-rate regime and thus gender differences should be smaller. Their results do indeed show that gender differences are smaller in the piece-rate regime. Meanwhile, Heywood and O'Halloran (2005) studied racial wage differences for men and found that the racial wage gap is smaller for those receiving individual outputbased pay as opposed to time-rate wages. Interestingly, they concentrated on men since preliminary estimates had shown that output-based pay did not increase the wages of women and that the gender wage gap is at least as large among those earning output-based pay.

Studies focusing on broader PRP measures rather than simple piece-rates include the work of Booth and Frank (1999), who used BHPS data and found that women are less likely to be in PRP jobs and that PRP raises their earnings as much as those of men. ${ }^{1}$ Drolet (2002) used cross-sectional data and found that PRP has very little impact on gender wage differences. These results are in contrast to studies that only consider piece rates. Contrary to these findings, de la Rica et al. (2010) show that in Spain, the gender gap under PRP is larger than the gender gap under the regular wage.

Theoretical work on the wage and productivity effects of PRP emphasises the selection of individuals on the basis of ability, and the selection of firms on the basis of the monitoring costs of PRP plans. Also, earlier literature on the effects of PRP on wages has shown the importance of controlling for such effects (Lazear 2000, Pekkarinen and Riddell 2008). However, many of the papers studying the impact of PRP on gender wage differentials use cross-sectional data and cannot therefore control for person and firm effects.

Furthermore, none of the papers contrast different types of PRP plans. For example, the nature of the work and the compensation systems of blue- and white-collar employees are very different (Fama 1991). White-collar workers are typically paid monthly salaries, while blue-collar are paid by the hour. The PRP components also differ between the employee groups. We distinguish two types of PRP plans, namely, 1) piece rates and reward rates and 2) bonuses. The first difference between the employee groups is that blue-collar workers are often paid piece or reward rates, while such methods of payment are practically non-existent for white-collar workers in manufacturing. The second difference is that bonus plans may be different; for example, the performance measures and the organisational level of the performance measures may differ. These differences in PRP components may generate different wage effects and different effects on gender wage differences.

Amuedo-Dorantes and de la Rica (2006) study gender differences in wage complements using cross-sectional data. They find large gender differences in the wage complements. However, these wage complements include many things other than PRP. 
We use a large Finnish linked employer-employee panel data set to examine the impact of PRP on gender wage differences. We control for unobservable person and firm characteristics, thus improving on the existing literature. For blue-collar employees we can distinguish piece and reward rates from other forms of PRP. Throughout the paper, we single out piece rates and reward rates and call all other forms of PRP "bonuses". To examine how different types of PRP affect gender wage differences, we estimate separate effects for piece rates and reward rates versus bonuses.

Using OLS, we find that that i) bonus pay increases wages; ii) bonus pay decreases gender wage differentials; and iii) firms adopting a bonus plan pay higher wages even before adopting it. For blue-collar employees, we find that piece rates and reward rates increase wages more than bonuses and that they tend to increase gender wage differentials.

Accounting for unobserved person and firm effects changes the results concerning bonuses; in contrast to the OLS results, the adoption of a bonus plan increases earnings quite similarly for both men and women. Women's earnings increase slightly less compared to men's, but the economic significance of the difference is negligible. This comparison to OLS results highlights the importance of controlling for person and firm effects. When comparing blue- and whitecollar employees, we find that PRP increases blue-collar wages more than those of white-collar employees but its impact on the gender wage gap is smaller for blue-collar employees. However, piece rates and reward rates increase wages more for men than women.

The structure of the paper is as follows. The next section discusses the reasons for using PRP and the differences in compensation for blue- and white-collar employees. This is followed by a discussion of the channels through which PRP may affect gender wage differentials. The empirical part of the paper begins by describing the study's data and econometric approach, after which results are presented. The final section concludes.

\section{Choice of compensation structure and the gender wage gap}

In this section, we consider the choice between time-rate and incentive pay and why blue- and white-collar employees are compensated differently. We also discuss how the gender wage gap may be affected by the compensation structure.

In the basic neoclassical model, it is assumed that the wage always equals the marginal product of a worker. However, it is widely recognised that this is not always the case, not least because the real productivity (or effort) of a worker is not directly observable to the employer, and measuring it to operate a pay system based on productivity is costly. There may also be significant costs of making a contract complex enough to cover all aspects of a worker's performance. Firm heterogeneity with respect to the cost of performance measurement thus affects the choice of compensation structure. Characteristics of the job also have an impact on the appropriate and available performance measures, which in turn affect the optimal compensation scheme.

Broad performance measures, such as profitability, include all or most of the factors that the employee can control, but they typically also include a variety of uncontrollable factors. Uncontrollable risk is problematic since a risk-averse employee has to be compensated for carry- 
ing such risk (Holmstrom 1979). Narrower measures, such as productivity, are less risky but tend to exclude some controllable aspects, which may lead to distortions when the employee's actions have a different impact on the performance measure and the goals of the organisation. Thus, risk and distortion usually are inversely related; a measure that has a low risk is often relatively distorted (Baker 2002).

A common way of improving the trade-off between distortion and risk is using subjectivity in performance measurement (Gibbs et al. 2004). Subjective measures may decrease distortion if they can better take into account the goals of organisation. Thus, subjective measures are more likely to be used in complex jobs where distortions easily arise.

Blue- and white-collar employees thus have different kinds of incentive plans. For example piece rates are typically not feasible for white-collar employees since i) their output is hard to define and measure and ii) piece rates would create distorted incentives. For blue-collar employees, the measurement of output is less of an issue (although it is by no means trivial), and narrower tasks and decision rights mean that piece rates do not necessarily distort incentives. Differences in performance measures also lead to differences in the intensity of incentives. The better the available performance measures are, the stronger the incentives can be.

In addition to exerting higher effort, PRP plays a role in sorting employees to jobs and employers. If the employees have heterogeneous productivity, PRP helps in attracting the most productive employees. Lemieux et al. (2009) emphasise that sorting employees is more valuable when the marginal value of effort is higher and the conditional variance of ability is higher (conditional on observed characteristics). This implies that PRP is more likely in managerial jobs (where the marginal value of effort is higher) and among highly skilled workers (where the variance of ability is higher).

The economic literature on gender wage differentials has identified multiple reasons why women and men have generally different levels of earnings. Basically, there are two types of arguments. The first is concerned with differences in human capital. Due to the higher incidence of expected career breaks, women make different human capital choices (both education and on-the-job training choices), and this in turn leads to job segregation. Many studies have shown that segregated labour markets are the main reason for gender wage differences (e.g. Meyersson Milgrom et al. 2001, Korkeamaki and Kyyra 2006, Wolf and Heinz 2007). The other main argument is based on labour market discrimination.

Performance-related pay increases wages due to its impact on selection and effort (Lazear 2000, Pekkarinen and Riddell 2008). Tying pay to performance attracts high-ability employees and provides incentives to increase effort. Thus, PRP may affect the gender wage gap through several mechanisms: 1) discrimination, 2) segregation, 3) differences in selection effects between sexes and 4) differences in effort effects. We now consider each of these mechanisms.

Discrimination. Much of the earlier literature has considered the impact of PRP plans, especially piece rates, on discrimination. Piece rates are likely to leave little scope for discrimination due to their objective nature (e.g. Jirjahn and Stephan 2004). Thus, it has been argued that gender wage differences should be smaller in piece-rate jobs than in other jobs. However, piece-rates are a particular form of PRP, one that is becoming less common. As pointed out above, optimal performance pay does not in each case depend on the reliably measured out- 
put of the individual. Typically, the performance measures include several quantitative measures, and in addition, subjective measures of (actual or relative) performance may be used. Such subjective ratings may reflect a bias in the perception or attitudes of a supervisor. Moreover, individuals within the same performance pay scheme may also have different tasks, some of which result in a higher potential pay than others. Discrimination may therefore still play a role in the assignment to tasks.

An important issue in the context of the Finnish private sector is that many of the recently introduced performance related pay schemes are partly based on the performance of a team, division or even that of the whole company. In many of these schemes, all members of the team receive the same bonus, which depends on the overall performance of the team. Such plans leave less room for sex discrimination.

Segregation. PRP is not indiscriminately used in all types of jobs and for all individuals. Segregation by gender into occupations or firms may result in differences in the incidence of performance-related pay, even if performance pay per se is not dependent on gender. Some firms have a higher proportion of jobs suitable for the use of performance pay than others. It may be, however, difficult to differentiate between the impact of gender and occupational and industry characteristics, especially if female dominance is correlated with job characteristics.

PRP and effort. The impact on productivity may also be different for men and women, as individuals set their effort to achieve the outcome that is personally optimal for them. Division of labour within the family may affect effort choices in the labour market (Becker 1985). Empirical evidence indicates that housework affects wages negatively, especially for married women (Hersch and Stratton 1997, Hersch and Stratton 2002).

$P R P$ and selection. Once it is known that certain jobs apply performance pay, there is also a selection process whereby only those workers who actually benefit from performance pay (and benefit the firm) enter these jobs or stay in them. This selection effect may differ between sexes for many reasons. First, there are reasons related to the division of labour in the household that may affect what kind of compensation plans men versus women prefer. Family responsibilities may lead to a higher degree of randomness in women's output (and lower productivity), leading to a preference for fixed wage schemes. However, higher levels of discrimination and more intermittent careers may lead to women to prefer piece rates and other types of performance pay that depend on instantaneous productivity. In these schemes, they reap the benefits of their productivity increases instantly, unlike in jobs where increasing productivity requires extensive learning and the compensation for effort is received later. Geddes and Heywood (2003) point out that some forms of performance pay, for example commission pay for sales, actually favour longer tenure and commitment as returns to effort occur with a delay. Parent (2001) observes that profit-sharing may serve as a way of rewarding firm-specific skills. Empirical studies show that profit-sharing is related to higher productivity, though less so for women (Parent 2001). Women who generally have lower levels of labour force attachment may be less influenced by such incentives.

Second, experiments (Dohmen and Falk Forthcoming) show that individuals with higher risk tolerance and confidence tend to choose piece-rate pay schemes. These characteristics differ between genders on average (Croson and Gneezy 2009), and therefore, different types of pay schemes may be optimal for men versus women. Third, the degree of labour market mobility 
and reasons for mobility, differ between sexes. Men tend to be more mobile (Keith and McWilliams 1999), and their labour market transitions are more often motivated by monetary issues (Manning 2003).

Thus, it is clear that PRP may affect the gender wage gap through many channels, and the effects may differ between types of PRP plans. However, it is difficult to make any firm predictions based on these arguments.

\section{$3 \quad$ Institutional setting}

This section outlines some pertinent features of Finnish labour markets, focusing on the wage systems of blue- and white-collar employees.

Our analysis concentrates on two separate employee groups. The first, blue-collar employees, consists of hourly wage, non-managerial, non-supervisory employees who are mostly low skilled and without post secondary education. The second group, white-collar employees, includes salaried clerical employees, supervisors, managers and other upper white-collar employees.

An important difference between these two groups concerns base pay mechanisms. The hourly wages of blue-collar employees are fixed hourly wages, piece rates or reward rates, or some combination of these $\mathrm{e}^{2}$. The minimum hourly wage rates for given job-complexity levels are defined in a collective agreement, and these agreements also provide guidelines for setting the piece rates or stipulate the rates. White-collar employees receive a monthly salary. For clerical employees, minimum wages for different jobs are stipulated in the collective agreements, while the wage setting of upper white-collar employees is based on bargaining on a personal level.

Bonuses in the Finnish labour markets are usually defined as wage supplements that augment base pay mechanisms and are based on meeting financial or operative targets. In practice, this definition covers all usual performance-related pay components, except those stipulated in collective agreements for blue-collar employees, e.g., piece rates and reward rates. Bonuses are completely outside the collective bargaining system for all employee groups. Thus, any decisions concerning bonuses can be made unilaterally by the employer.

In sum, the income of white-collar employees is based on fixed salary and possible bonus payments. For blue-collar employees, income consists of hourly wages (i.e., fixed, reward and piece rates) and possible bonus payments. Thus, blue-collar employees have two kinds of incentive elements, namely, hourly reward rates and piece rates, on the one hand, and bonus payments, on the other.

Information on bonus plan features is available from a representative survey from Finnish manufacturing (EK The Conferederation of Finnish Industries 2006). Bonus plans typically have three to four performance measures, with the most common measures being profitabil-

2 Piece rates are based on quantity of output, whereas reward rates may also be based on quality of output or other measures of performance. 
ity, product or service quality, productivity, development goal and cost savings. Performance measurement typically takes place at two to three organisational levels, the most common being the company, profit centre and team. Bonuses make up roughly $4 \%$ of annual earnings for blue-collar workers and 5-6\% for white-collar workers. The bonuses are usually paid once a year.

Finally, we note that the Act on Equality between Men and Women (effective since 1.1.1987) prohibits setting different conditions of employment for men and women. The Act is very broad in terms of its applicability such that gender discrimination with respect to PRP would be illegal.

\section{$4 \quad$ Data and econometric approach}

We use wage data from the Confederation of Finnish Industries (EK), which is the central organisation of employer associations. The main industries covered by the data are manufacturing, construction, energy and transportation. Member firms of EK employ the majority of employees in manufacturing and roughly every third Finnish employee. Wage data are based on an annual survey of employers and, except for the smallest firms, a response is mandatory for member firms. Wage data are used in collective bargaining and form the basis of the private sector wage structure data maintained by Statistics Finland, the country's statistical authority. The information we use here thus comes from the wage records of firms and is highly reliable. The data contain on average around 370000 persons and 3500 firms annually. There are 730793 unique persons in the data and 3884 unique firms.

The data include detailed information on wages, working time and individual characteristics as well as unique person and firm identifiers. Thus, it forms a linked employer-employee panel that allows for following persons over time, possibly in different firms.

Wage variables differ for blue- and white-collar employees. For blue-collar employees, the data include total wages earned by working on fixed hourly rate, reward rates and piece rates, as well as hours worked on each type of rate for the quarter during which the survey was completed. Bonus pay is recorded at the annual level, and fortunately, the data also include hours worked at the annual level. The hourly earnings are calculated as hourly wages divided by hours worked plus performance-related pay divided by annual hours worked. For white-collar employees, hourly earnings are calculated as monthly earnings (inclusive of base salary, bonuses, and other minor wage supplements) divided by contract hours.

The data include information on bonus payments but lack information on the existence of a bonus plan. Thus, we have to infer from the data whether the firm has a bonus plan or not for a particular employee group. We define a firm as having a bonus plan for an employee group (that is, blue- and white-collar workers) after it has paid bonuses for at least one employee in an employee group. Implicitly, this definition makes two assumptions. First, we assume that firms do not discontinue these plans. Second, we assume that the plan always applies to the entire employee group. These assumptions can be defended in light of survey evidence covering the same population of firms. First, a survey from 2005 shows that under $1 \%$ of employees in manufacturing are in firms that plan to curtail the PRP plan (EK The Conferederation of Finnish Industries 2006). Second, usually over $85 \%$ of an employee group is covered by the bonus 
plan if it is in place (Kauhanen and Napari 2010). As a robustness check, we use a similar definition as Lemieux et al. (2009), according to which a person is classified to be in a bonus job if she is paid bonus payments at least once during the employment spell.

For piece and reward rates, the situation is simpler. We use actual payments to classify employees. This is possible since working under a piece-rate contract and receiving piece-rate payments are equivalent.

Personal characteristics include age, sex, level and field of education, tenure and job title. The data include fewer firm characteristics, mainly on industry (or field of collective agreement), but it allows for the construction of firm size, for example.

\subsection{Descriptive statistics}

Figure 1 shows the incidence of PRP in 1998-2007. The left panel concentrates on blue-collar employees. The number of employees in a bonus plan increased notably from 1998 to 2002, after which growth has been slower. Men were more likely to be in bonus plans in 1998 than women, but by 2002, the roles were reversed. In addition, men work in piece-rate jobs more often than women, although this prevalence has been declining for both sexes. The right panel shows white-collar employees; throughout the observation period, bonus plans have been more common for white-collar than blue-collar workers. Also, growth has been slower for white-collar workers. Men are slightly more often in bonus plans as compared to women.

\section{Figure 1 Incidence of PRP over time by gender}
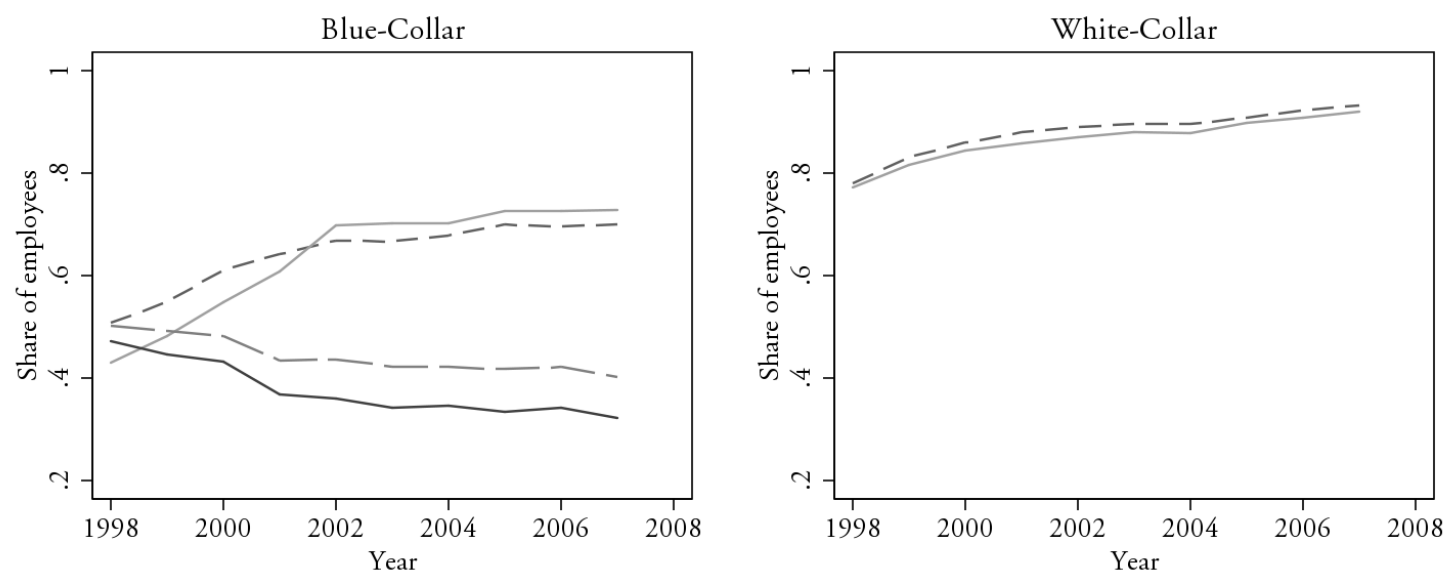

$$
\begin{aligned}
& ----- \text { Men, bonuses } \\
& - \text { Women, bonuses } \\
& --- \text { Men, piece- and reward-rates } \\
& - \text { Women, piece- and reward-rates }
\end{aligned}
$$

An employee is in a bonus plan if she is employed in a firm that has paid bonuses to at least one employee in her employee group. 
Figure 2 Gender wage differentials by PRP status
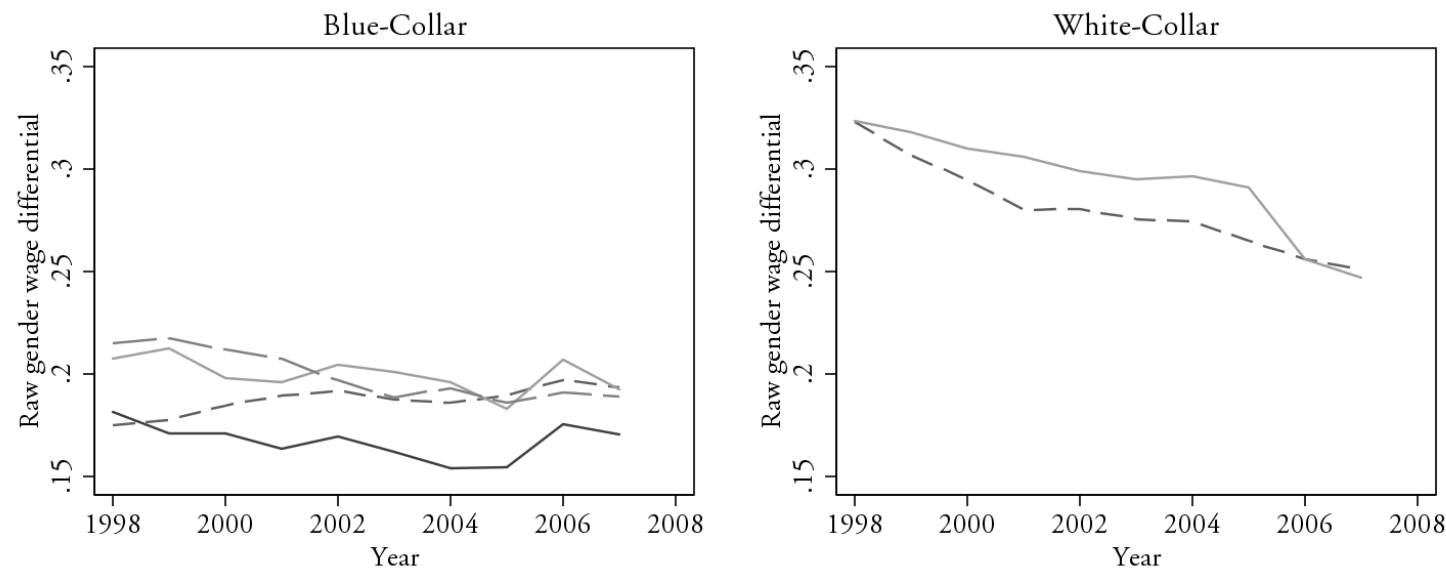

$$
\begin{array}{ll}
----- & \text { Bonus plans } \\
- & \text { Not in bonus plans } \\
- & \text { Piece and reward rates } \\
- & \text { No piece and reward rates }
\end{array}
$$

An employee is in a bonus plan if she is employed in a firm that has paid bonuses to at least one employee in her employee group.

Gender wage differentials over time according to PRP status are shown in Figure 2. According to the left panel, gender wage differentials in all categories have been quite stable, and gender wage differentials are lowest for persons who are not paid piece rates or reward rates. The right panel shows that the gender wage differentials have been larger for white-collar than blue-collar workers, and the wage differentials have reduced over time. The wage differentials have consistently been lower in firms using bonuses as compared to other firms.

\subsection{The empirical approach}

We estimate the following equation to study the impact of both bonuses as well as piece and reward rates on gender wage differences.

In $w_{i t}=\mathbf{x}_{i t} \beta+\gamma_{1} b_{i t}+\gamma_{2} b_{i t} f_{i}+\gamma_{3} b \_e v e r_{i t}+\gamma_{4} b_{-} e v e r_{i t} f_{i}$

$+\gamma_{5} \operatorname{prr}_{i t}+\gamma_{6} \operatorname{prr}_{i t} f_{i}+\theta_{i}+\psi_{J(i, j)}+\varepsilon_{i t}$

$W_{i t}$ is the hourly wage. The vector $\mathbf{x}_{i t}$ includes age, tenure, level of education (six categories), field of education (10 categories), job title dummies (243 categories) white-collar dummy, upper whitecollar dummy, firm size (four categories), industry (73 categories) and year dummies. The bonus dummy is denotes as $b_{i t}$, the female dummy is $f_{i}$, and the dummy for firms that eventually adopt 
a bonus plan is $b \_e v e r_{i t}{ }^{3}$. The piece or reward rate dummy is denoted by prr $_{i t}$. The person effect is $\theta_{i}$, and the firm effect is $\psi_{J(i, j)}$. The person and firm effects are subsumed in the error term in OLS estimation.

As discussed above, PRP may affect gender wage differentials through discrimination, segregation and differences in effort and selection effects. We control for segregation by including job title dummies as well as firm effects. The selection effects in turn are captured by the person and firm effects.

The key coefficients of interest concerning bonuses are $\gamma_{1}$ through $\gamma_{4}$. Their interpretations are as follows. $\gamma_{1}$ measures the wage gain from being in a bonus plan for men, while $\gamma_{2}$ shows if the effect is different for women. Permanent differences in wage levels between firms that eventually adopt a bonus plan and others are captured by $\gamma_{3}$, while $\gamma_{4}$ shows if this difference is dissimilar for women. When we include firm and person effects in the estimation, the coefficients $\gamma_{3}$ and $\gamma_{4}$ are not identified, since they are collinear with the person and firm effects. The effect of piece and reward rates on wages is captured by $\gamma_{5}$, while $\gamma_{6}$ shows the differential impact for women. These coefficients are identified for the blue-collar employees.

The OLS estimation of equation (1) provides a useful starting point, but the fact that firm and person effects are in the error term may yield misleading results if these are correlated with the adoption of PRP. More specifically, it may be the case that particularly productive employees participate in PRP plans (e.g. Lazear 2000) and that permanent firm characteristics may influence the adoption of PRP plans. Thus, controlling for these factors is important.

When conducting the fixed effect estimations, we must consider whether we can we safely assume that the individual effect stays fixed over time. In principle, a firm-person match value may change over time, and this effect may not be independent of the introduction of performance pay. For example, individuals who experience a significant earnings growth (i.e. an increasing match value) may be more likely to stay after a change in the wage scheme. This would result in a positive "treated" effect, and if the selection is stronger for either gender, it would influence the observed difference in the gender gap.

\section{$5 \quad$ Results}

\subsection{OLS estimation}

According to the first column in Table 1, firms paying bonuses pay higher wages even before the adoption of the bonus plan, while gender differences are not notably different from other firms. The adoption of a bonus plan raises wages around 3\% for men and over $4 \%$ for women. Piece rates and reward rates increase wages by around $11 \%$ for men and a little less for women.

As noted earlier, the differences in the nature of jobs and the wage setting motivate separate analyses for blue- and white-collar employees. The results for blue-collar workers are in the

\footnotetext{
3 Note that if we were to include all interactions among terms $b_{i t}, f_{i}$ and $b_{-}$ever ${ }_{i t}$, the equation would also include terms $b_{i t} \cdot b_{-}$ever and $b_{i t} \cdot f_{i t} \cdot b_{-}$ever ${ }_{i t}$. These, however, drop out of the equation since $b_{i t} \cdot b_{-}$ever ${ }_{i t}=b_{i t}$ and $b_{i t} \cdot f_{i t} \cdot b_{-}$ever ${ }_{i t}=b_{i t} \cdot f_{i t}$ by definition of $b_{i t}$.

4 We use the stata program "felsdvreg" to estimate the models with firm and person effects (see Cornelissen (2008)).
} 


\begin{tabular}{|c|c|c|c|}
\hline \multirow[t]{3}{*}{ Table 1} & e differentials & & \\
\hline & \multicolumn{3}{|c|}{ OLS estimation } \\
\hline & All & Blue-collar & White-collar \\
\hline \multirow[t]{2}{*}{ Bonus plan } & $0.034 * * *$ & $0.043 * * *$ & $0.023 * * *$ \\
\hline & $(0.001)$ & $(0.001)$ & $(0.002)$ \\
\hline \multirow[t]{2}{*}{ Bonus plan ever } & $0.005 * * *$ & $-0.010 * * *$ & $0.031 * * *$ \\
\hline & $(0.001)$ & $(0.001)$ & $(0.003)$ \\
\hline \multirow[t]{2}{*}{ Bonus plan*female } & $0.012 * * *$ & $0.016^{* * *}$ & $0.020 * * *$ \\
\hline & $(0.001)$ & $(0.002)$ & $(0.003)$ \\
\hline \multirow[t]{2}{*}{ Bonus plan ever*female } & 0.001 & $0.009 * * *$ & $-0.021 * * *$ \\
\hline & $(0.002)$ & $(0.002)$ & $(0.004)$ \\
\hline \multirow[t]{2}{*}{ Piece rate or reward rate } & $0.088^{* * *}$ & $0.087 * * *$ & \\
\hline & $(0.001)$ & $(0.001)$ & \\
\hline \multirow[t]{2}{*}{ Piece rate or reward rate*female } & $-0.003 * * *$ & $-0.011 * * *$ & \\
\hline & $(0.001)$ & $(0.001)$ & \\
\hline Observations & $3,019,278$ & $1,610,239$ & $1,409,039$ \\
\hline R-squared & 0.657 & 0.527 & 0.641 \\
\hline
\end{tabular}

second column of Table 1. The results show that firms eventually adopting a bonus plan pay lower wages before adoption, while gender differences are smaller than in other firms. Participating in a bonus plan raises wages around $4 \%$ for men and almost $6 \%$ for women. Piece and reward rates increase wages around $9 \%$ for men and around $8 \%$ for women.

The results for white-collar employees in the third column are different. Firms eventually adopting a bonus plan pay higher wages even before adoption, and the gender differences are larger than in other firms. Similarly to blue-collar workers, participating in a bonus plan raises wages, and it raises female wages a little more than male wages. The magnitudes, however, are smaller. Male wages rise only slightly over $2 \%$, while female wages rise over $4 \%$.

The OLS results show that adoption of a bonus plan reduces the gender wage differentials. These results also show that the firms that never adopt a bonus plan are systematically different from the ones that do adopt. Moreover, the differences between firms using bonuses and others with respect to wage levels and the gender wage gap are quite different for blue- and white-collar employees. Next, we move to describe results that take unobserved individual and firm heterogeneity into account.

\subsection{Individual and firm effects}

Table 2 shows the results from estimations that control for unobserved time-invariant firm and person effects. The first column shows that employees in bonus plans earn around $2 \%$ more than other employees. The magnitude is somewhat smaller for women, but the difference is of little significance economically (around one-third of a percent). Piece and reward rates increase wages by $6 \%$ for men but around $5 \%$ for women. The results for blue- and white- 


\begin{tabular}{|c|c|c|c|}
\hline \multirow{2}{*}{ Table 2} & \multicolumn{3}{|c|}{ Estimation including Person and Firm Effects } \\
\hline & All & Blue-collar & White-collar \\
\hline Bonus plan & $\begin{array}{l}0.021 \text { *** } \\
(0.000)\end{array}$ & $\begin{array}{l}0.030^{* * *} \\
(0.001)\end{array}$ & $\begin{array}{l}0.017^{* * *} \\
(0.001)\end{array}$ \\
\hline Bonus plan*female & $\begin{array}{l}-0.004 \text { *** } \\
(0.001)\end{array}$ & $\begin{array}{l}-0.002 * * \\
(0.001)\end{array}$ & $\begin{array}{l}-0.008^{* * *} \\
(0.001)\end{array}$ \\
\hline Piece rate or reward rate & $\begin{array}{c}0.061^{* * *} \\
(0.000)\end{array}$ & $\begin{array}{l}0.057^{* * *} \\
(0.000)\end{array}$ & \\
\hline Piece rate or reward rate*female & $\begin{array}{l}-0.010 * * * \\
(0.001)\end{array}$ & $\begin{array}{l}-0.018^{* * *} \\
(0.001)\end{array}$ & \\
\hline Observations & $3,019,278$ & $1,610,239$ & $1,409,039$ \\
\hline
\end{tabular}

*** $p<0.01,{ }^{* *} p<0.05,{ }^{*} p<0.1$ Standard errors are given in parenthesis. Other variables included are: level and field of education, jobtitle dummies, age, tenure, white-collar dummy, firm size, and industry.

collar employees are qualitatively similar with respect to bonuses. However, the wage effect is stronger for blue-collar employees as compared to white-collar workers. The gender difference is also smaller for blue-collar workers.

As compared to the OLS results for bonuses, the results in Table 2 are quite different. The OLS results show that the adoption of a bonus plan reduces the gender wage gap, while here we find no such evidence. However, the results concerning piece and reward rates are similar in that we find that these forms of PRP increase gender wage differentials, as evident in both Table 1 and Table 2 .

The sizes of the effects found here are of similar magnitude as, for example, the results of Lemieux et al. (2009). Using U.S. data, they find that working in a PRP job increases wages by $6 \%$, and actually receiving PRP payments brings an additional $8 \%$ wage gain. Controlling for individual fixed effects reduces the effects to $2 \%$ for working in a PRP job and $4 \%$ for receiving PRP payments. Pekkarinen and Riddell (2008) study the wage effects of piece rates and reward rates in the Finnish metal industry. They find that a shift from time rates to reward rates increases wages by $8 \%$ for men and $9 \%$ for women. Controlling for individual and firm fixed effects reduces these figures to $5 \%$ and $7 \%$, respectively. Results for piece rates are qualitatively similar but quantitatively larger.

The results concerning the gender wage gap suggest that some of the effects discussed in the earlier section are not strong, nor do they offset each other. The fact that the gender wage gap is larger for blue-collar workers who work under piece-rate or reward-rate schemes seems to imply that there is no large scale pay discrimination against women working on time rates, assuming that the access to piece-rate jobs is not limited for women. However, it is possible that women indeed are able to provide less effort because of family responsibilities, which might explain the larger gender gap in piece-rate jobs. Lower mobility might also explain why women with high ability are not able to select into these jobs as efficiently as men.

The impact of bonus schemes on the gender gap is minimal for blue-collar workers. This may naturally be a result of similar productivity of men as compared to women in these jobs as well 
as equal treatment. It may also be indicative of the fact that for blue-collar jobs, bonus schemes are in general of less significance, as the measurability of output also allows the use of traditional piece-rate schemes. Bonus schemes are possibly used less often to provide individual or small team incentives for blue-collar workers. If the aim is to reward large employee groups on an equitable basis by awarding everyone bonuses of the same relative or absolute magnitude, the schemes may have a minimal impact on the wage gap or in general on wage differentials between workers and worker groups.

For white-collar employees, the impact of bonuses on the gender gap is slightly more significant. This may be due to the factors mentioned above regarding piece rate and reward pay if the bonuses for white-collar workers are dependent on individual performance or that of a small team.

\subsection{Robustness checks: other definitions}

We have defined a firm to have a bonus plan for an employee group (i.e., blue- and white-collar workers) after it has paid bonus payments for at least one employee in an employee group. There are naturally other ways to define participation in a bonus plan. In this section, we show that our findings are robust to alternative definitions. We discuss only the results concerning bonuses, since the results for reward rates and piece rates are very similar to the results in $\mathrm{Ta}$ ble 1 and Table 2 .

We employ two definitions that are based on a person being in a job that involves bonuses. The first definition (Def 1) follows Lemieux et al. (2009). According to this definition, a person is in a bonus plan if the person receives bonus payments at least once during an employment relation. The employment relation here means a spell of observations for a person in a given firm. The second definition (Def 2) states that a person is in a bonus plan after that person has first received bonus payments during an employment relationship. The difference between these definitions is that the first classifies an entire whole employment relationship as involving bonus pay or not, whereas the second definition may change during an employment relationship depending on the timing of the payments.

Table 3 shows the results of an analysis similar to Table 1 and Table 2. The first panel uses Def 1 in OLS estimation. The results are qualitatively similar to Table 1; employees in bonus plans earn more, and the gender differences are somewhat smaller for employees participating in bonus plans. The figures are a bit larger as compared to Table 1 . The second panel adds person and firm effects. Again, the conclusions are similar to Table 2; bonuses increase earnings but have little effect on the gender wage gap. Although for white-collar employees, the gender gap seems to be a bit smaller, the economic significance is negligible. Panel three uses Def 2 in OLS estimation, with results that are very similar to those under Def 1 . Panel four adds person and firm effects. This somewhat changes the results concerning the gender wage gap. When the estimations are done separately for blue- and white-collar employees, the results show a gender gap for employees in bonus plans. However, the economic significance is small for blue-collar employees. For white-collar employees, results show a gender gap of $1 \%$ greater than that for employees in bonus plans. All in all, the results support the conclusion that OLS tends to show bonus pay decreasing the gender wage gap, while accounting for person and firm effects leads to the conclusion that the gender wage gap is mostly unchanged. 
Table 3 PRP and gender wage differentials: job definitions for bonuses

\begin{tabular}{lccc} 
& \multicolumn{3}{c}{ OLS estimation (Def 1) } \\
& All & Blue-collar & White-collar \\
Bonus plan & $0.052^{* * *}$ & $0.045^{* * *}$ & $0.064^{* * *}$ \\
& $(0.001)$ & $(0.001)$ & $(0.001)$ \\
Bonus plan*female & $0.015^{* * *}$ & $0.026^{* * *}$ & $0.003^{*}$ \\
& $(0.001)$ & $(0.001)$ & $(0.002)$ \\
Piece rate or reward rate & $0.092^{* * *}$ & $0.090^{* * *}$ & \\
Piece rate or reward rate*female & $(0.001)$ & $(0.001)$ & \\
& $-0.003^{* *}$ & $-0.010^{* * *}$ & \\
Observations & $(0.001)$ & $(0.001)$ & $1,409,039$ \\
R-squared & $3,019,278$ & $1,610,239$ & 0.645 \\
& 0.660 & 0.530 &
\end{tabular}

\begin{tabular}{lccc} 
& \multicolumn{3}{c}{ Estimation with Person and Firm Effects (Def 1) } \\
& All & Blue-collar & White-collar \\
Bonus plan & $0.049^{* * *}$ & $0.048^{* * *}$ & $0.048^{* * *}$ \\
& $(0.001)$ & $(0.001)$ & $(0.001)$ \\
Bonus plan*female & $0.002^{*}$ & 0.002 & $0.002^{* *}$ \\
& $(0.001)$ & $(0.002)$ & $(0.001)$ \\
Piece rate or reward rate & $0.061^{* * *}$ & $0.056^{* * *}$ & \\
Piece rate or reward rate*female & $(0.000)$ & $(0.000)$ & \\
& $-0.010^{* * *}$ & $-0.018^{* * *}$ & \\
Observations & $(0.001)$ & $(0.001)$ & $1,409,039$
\end{tabular}

\begin{tabular}{lccc} 
& \multicolumn{3}{c}{ OLS estimation (Def 2) } \\
& All & Blue-collar & White-collar \\
Bonus plan & $0.059^{* * *}$ & $0.052^{* * *}$ & $0.068^{* * *}$ \\
& $(0.001)$ & $(0.001)$ & $(0.001)$ \\
Bonus plan*female & $0.012^{* * *}$ & $0.021^{* * *}$ & $0.004^{* * *}$ \\
& $(0.001)$ & $(0.001)$ & $(0.001)$ \\
Piece rate or reward rate & $0.093^{* * *}$ & $0.091^{* * *}$ & \\
Piece rate or reward rate *female & $(0.001)$ & $(0.001)$ & \\
& $-0.003^{* * *}$ & $-0.010^{* * *}$ & \\
Observations & $(0.001)$ & $(0.001)$ & \\
R-squared & $3,019,278$ & $1,610,239$ & $1,409,039$ \\
& 0.662 & 0.532 & 0.647
\end{tabular}

\begin{tabular}{lccc} 
& \multicolumn{3}{c}{ Estimation with Person and Firm Effects (Def 2) } \\
& All & Blue-collar & White-collar \\
Bonus plan & $0.054^{* * *}$ & $0.048^{* * *}$ & $0.060^{* * *}$ \\
& $(0.000)$ & $(0.000)$ & $(0.000)$ \\
Bonus plan*female & 0.001 & $0.006^{* * *}$ & $-0.011^{* * *}$ \\
& $(0.000)$ & $(0.001)$ & $(0.001)$ \\
Piece rate or reward rate & $0.062^{* * *}$ & $0.058^{* * *}$ & \\
Piece rate or reward rate *female & $(0.000)$ & $(0.000)$ & \\
Observations & $-0.009^{* * *}$ & $-0.017^{* * *}$ & \\
\hline
\end{tabular}

*** $p<0.01,{ }^{* *} p<0.05,{ }^{*} p<0.1$ Standard errors are robust for heteroscedasticity and autocorrelation in OLS estimation and are given in parenthesis. Regular standard errors are used in the person and firm effects estimation Other variables included are: female dummy, level and field of education, jobtitle dummies, age, tenure, whitecollar dummy, firm size, and industry. Bonus plan (Def 1) equals unity if the person receives bonus payments at least once during an employment relation (This follows Lemieux et al 2009). Bonus plan (def 2) equals unity after the person has first received bonus payments during an employment relationship. 


\section{Conclusion}

We study the impact of performance-related pay on the gender wage gap using Finnish linked employer-employee panel data. Controlling for unobserved person and firm effects, we find that bonuses increase earnings quite similarly for both men and women. Women's earnings increase slightly less as compared to men's, but the economic significance of the difference is negligible. Thus, bonus pay has little implication for the gender wage gap. Piece rates and reward rates, however, tend to increase gender wage differentials. Thus, the nature of the PRP plan is important for understanding the impact of PRP on gender wage differentials. Piece rates and reward rates measure performance mainly at a personal level, while performance measures in bonus plans range from individual level to company level. This is one potential explanation for the differences in the impact on gender wage differentials.

A comparison with OLS results suggests that it is important to control for unobserved person and firm effects. Using OLS, we find that that i) bonus pay increases wages; ii) bonus pay decreases gender wage differentials; and iii) firms adopting a bonus plan pay higher wages even before adopting it. While the OLS results suggest that bonuses maybe helpful in reducing the gender wage gap, our preferred results that control for individual and firm effects show that the OLS results are mainly due to sorting workers and firms into bonus plans. 


\section{References}

Amuedo-Dorantes, C. and De la Rica, S. (2006), "The role of segregation and pay structure on the gender wage gap: Evidence from matched employer-employee data for spain", B.E. Journal of Economic Analysis and Policy: Contributions to Economic Analysis and Policy 5: 1-32.

Baker, G. (2002), “Distortion and risk in optimal incentive contracts”, Journal of Human Resources 37: 728-751.

Becker, G.S. (1985), "Human capital, effort, and the sexual division of labor”, Journal of Labor Economics 3: S33-58.

Booth, A.L. and Frank, J. (1999), "Earnings, productivity, and performance-related pay", Journal of Labor Economics 17: 447-463.

Cornelissen, T. (2008), "The stata command felsdvreg to fit a linear model with two high-dimensional fixed effects", Stata Journal 8: 170-189.

Croson, R. and Gneezy, U. (2009), "Gender differences in preferences", Journal of Economic Literature 47: 448-474.

de la Rica, S., Dolado, J.J. and Vega, R. (2010), "Performance pay and the gender wage gap: Evidence from spain", Centre for Economic Policy Research, Discussion Paper no. 7936

Dohmen, T. and Falk, A. (Forthcoming), "Performance pay and multi-dimensional sorting - productivity, preferences and gender", American Economic Review.

Drolet, M. (2002), "Can the workplace explain canadian gender pay differentials?" Canadian Public Policy 28: S41-63.

EK The Conferederation of Finnish Industries (2006), "Tulospalkkaus yksityisellä sektorilla: Palkkausjärjestelmätiedustelu 2005"

Fama, E.F. (1991), "Time, salary, and incentive payoffs in labor contracts", Journal of Labor Economics 9: $25-44$.

Geddes, L.A. and Heywood, J.S. (2003), "Gender and piece rates, commissions, and bonuses", Industrial Relations 42: 419-444.

Gibbs, M.J., Merchant, K.A., Van Der Stede, W.A. and Vargus, M.E. (2004), “Determinants and effects of subjectivity in incentives", Accounting Review 79: 409-436.

Hersch, J. and Stratton, L.S. (1997), "Housework, fixed effects, and wages of married workers", Journal of Human Resources 32: 285-307.

Hersch, J. and Stratton, L.S. (2002), "Housework and wages", Journal of Human Resources 37: 217-229.

Heywood, J.S. and O'Halloran, P.L. (2005), "Racial earnings differentials and performance pay”, Journal of Human Resources 40: 435-452.

Holmstrom, B. (1979), "Moral hazard and observability", Bell Journal of Economics 10: 74-91. 
Jirjahn, U. and Stephan, G. (2004), "Gender, piece rates and wages: Evidence from matched employeremployee data", Cambridge Journal of Economics 28: 683-704.

Kauhanen, A. and Napari, S. (2010), "Performance measurement and incentive plans", Research Institute of the Finnish Economy, Discussion Papers 1216.

Keith, K. and McWilliams, A. (1999), "The returns to mobility and job search by gender", Industrial and Labor Relations Review 52: 460-477.

Korkeamaki, O. and Kyyra, T. (2006), “A gender wage gap decomposition for matched employer-employee data", Labour Economics 13: 611-638.

Lazear, E.P. (2000), "Performance pay and productivity”, American Economic Review 90: 1346-1361.

Lemieux, T., MacLeod, W.B. and Parent, D. (2009), "Performance pay and wage inequality", Quarterly Journal of Economics 124: 1-49.

Manning, A. (2003), Monopsony in motion: Imperfect competition in labor markets, Princeton and Oxford: Princeton University Press.

Meyersson Milgrom, E.M., Petersen, T. and Snartland, V. (2001), "Equal pay for equal work? Evidence from sweden and a comparison with norway and the u.S", Scandinavian Journal of Economics 103: 559-583.

Parent, D. (2001), "Incentive pay in the united states: Its determinants and its effects", CIRANO Working Papers 2001s-04, CIRANO.

Pekkarinen, T. and Riddell, C. (2008), "Performance pay and earnings: Evidence from personnel records", Industrial \& Labor Relations Review 61: 297-319.

Wolf, E. and Heinz, A. (2007), "How to limit discrimination? Analyzing the effects of innovative workplace practices on intra-firm gender wage gaps using linked employer-employee data". 


\section{Appendix}

\begin{tabular}{|c|c|c|c|c|c|}
\hline Table A1 Summary statistics & & & & & \\
\hline Variable & Obs & Mean & Std. Dev. & Min & Max \\
\hline Log hourly earnings & 3143215 & 2.633 & 0.331 & 1.413 & 6.824 \\
\hline PRP firm after adoption & 3143215 & 0.754 & 0.431 & 0 & 1 \\
\hline PRP firm ever & 3143215 & 0.826 & 0.379 & 0 & 1 \\
\hline PRP job (def 1) & 3143215 & 0.627 & 0.484 & 0 & 1 \\
\hline PRP job (def 2) & 3143215 & 0.512 & 0.500 & 0 & 1 \\
\hline Female & 3143215 & 0.286 & 0.452 & 0 & 1 \\
\hline Age & 3143215 & 41.066 & 10.697 & 18 & 64 \\
\hline Tenure & 3142041 & 11.705 & 10.952 & 0 & 52 \\
\hline Blue-Collar & 3143215 & 0.549 & 0.498 & 0 & 1 \\
\hline Clerical & 3143215 & 0.251 & 0.434 & 0 & 1 \\
\hline Upper-White Collar & 3143215 & 0.200 & 0.400 & 0 & 1 \\
\hline Piece or Reward Rate (for blue collars) & 3143215 & 0.297 & 0.457 & 0 & 1 \\
\hline \multicolumn{6}{|l|}{ Level of Education } \\
\hline Lower Secondary & 3143215 & 0.226 & 0.418 & 0 & 1 \\
\hline Upper Secondary & 3143215 & 0.445 & 0.497 & 0 & 1 \\
\hline Lowest Tertiary & 3143215 & 0.150 & 0.357 & 0 & 1 \\
\hline Bachelor & 3143215 & 0.102 & 0.302 & 0 & 1 \\
\hline Masters & 3143215 & 0.073 & 0.260 & 0 & 1 \\
\hline Doctoral or equivalent & 3143215 & 0.004 & 0.065 & 0 & 1 \\
\hline \multicolumn{6}{|l|}{ Field of Education } \\
\hline General & 3143215 & 0.277 & 0.448 & 0 & 1 \\
\hline Teacher Education and Educational Science & 3143215 & 0.001 & 0.033 & 0 & 1 \\
\hline Humanities and Arts & 3143215 & 0.011 & 0.104 & 0 & 1 \\
\hline Social Sciences & 3143215 & 0.124 & 0.329 & 0 & 1 \\
\hline Natural Sciences & 3143215 & 0.014 & 0.119 & 0 & 1 \\
\hline Technology & 3143215 & 0.502 & 0.500 & 0 & 1 \\
\hline Agriculture and Forestry & 3143215 & 0.023 & 0.149 & 0 & 1 \\
\hline Health and Welfare & 3143215 & 0.010 & 0.099 & 0 & 1 \\
\hline Services & 3143215 & 0.038 & 0.192 & 0 & 1 \\
\hline Other & 3143215 & 0.000 & 0.008 & 0 & 1 \\
\hline \multicolumn{6}{|l|}{ Firm Size } \\
\hline$<20$ & 3143215 & 0.018 & 0.133 & 0 & 1 \\
\hline $20-49$ & 3143215 & 0.041 & 0.198 & 0 & 1 \\
\hline $50-299$ & 3143215 & 0.233 & 0.423 & 0 & 1 \\
\hline$>299$ & 3143215 & 0.708 & 0.455 & 0 & 1 \\
\hline
\end{tabular}

Note: PRP job (Def 1) equals unity if the person receives PRP payments at least once during an employement relation (This follows Lemieux et al 2009). PRP job (def 2) equals unity after the person has first received PRP payments during an employment relationship. 




\section{Aikaisemmin ilmestynyt ETLAn Keskusteluaiheita-sarjassa Previously published in the ETLA Discussion Papers Series}

No 1234 Antti-Jussi Tahvanainen - Tuomo Nikulainen, Commercialiazation at Finnish Universities - Researchers' Perspectives on the Motives and Challenges of Turning Science into Business. 10.01.2011. 47 p.

No 1235 Heli Koski - Mika Pajarinen, Do Business Subsidies Facilitate Employment Growth? 04.01.2011. 20 p.

No 1236 Antti-Jussi Tahvanainen - Raine Hermans, Making Sense of the TTO Production Function: University Technology Transfer Offices as Process Catalysts, Knowledge Converters and Impact Amplifiers. 11.01.2011. $40 \mathrm{p}$.

No 1237 Jukka Lassila - Tarmo Valkonen, Julkisen talouden rahoituksellinen kestävyys Suomessa. 11.01.2011. $28 \mathrm{~s}$.

No 1238 Martin Kenney - Bryan Pon, Structuring the Smartphone Industry: Is the Mobile Internet OS Platform the Key. 10.02.2011. 24 p.

No 1239 Mika Maliranta - Reijo Mankinen - Paavo Suni - Pekka Ylä-Anttila, Suhdanne- ja rakennekriisi yhtä aikaa? Toimiala- ja yritysrakenteen muutokset taantumassa. 17.02.2011. $20 \mathrm{~s}$.

No 1240 Jyrki Ali-Yrkkö-Petri Rouvinen - Timo Seppälä-Pekka Ylä-Anttila, Who Captures Value in Global Supply Chains? Case Nokia N95 Smartphone. 28.02.2011. 22 p.

No 1241 Antti Kauhanen - Sami Napari, Gender Differences in Careers. 9.03.2011. 31 p.

No 1242 Mika Pajarinen - Petri Rouvinen - Pekka Ylä-Anttila, Omistajuuden vaikutus suomalaisen työllisyyden kasvuun ja pysyvyyteen. 16.03.2011. $27 \mathrm{~s}$.

No 1243 Rita Asplund - Sami Napari, Intangibles and the Gender Wage Gap. An Analysis of Gender Wage Gaps Across Occupations in the Finnish Private Sector. 22.03.2011. 2 p.

No 1244 Antti Kauhanen - Sami Napari, Career and Wage Dynamics. Evidence from Linked Employer-Employee Data. 25.03.2011.28 p.

No 1245 Kari E.O. Alho, Should Sweden Join the EMU? An Analysis of General Equilibrium Effects through Trade. 06.04.2011. $16 \mathrm{p}$.

No 1246 Heli Koski-Mika Pajarinen, The Role of Business Subsidies in Job Creation of Start-ups, Gazelles and Incumbents. 07.04.2011.21 p.

No 1247 Antti Kauhanen, The Perils of Altering Incentive Plans. A Case Study. 08.04.2011. 22 p.

No 1248 Rita Asplund - Sami Napari, Intangible Capital and Wages. An Analysis of Wage Gaps Across Occupations and Genders in Czech Republic, Finland and Norway. 11.04.2011. 18 p.

Elinkeinoelämän Tutkimuslaitoksen julkaisemat "Keskusteluaiheita" ovat raportteja alustavista tutkimustuloksista ja väliraportteja tekeillä olevista tutkimuksista. Tässä sarjassa julkaistuja monisteita on mahdollista ostaa Taloustieto Oy:stä kopiointi- ja toimituskuluja vastaavaan hintaan.

Papers in this series are reports on preliminary research results and on studies in progress. They are sold by Taloustieto Oy for a nominal fee covering copying and postage costs.

Julkaisut ovat ladattavissa pdf-muodossa osoitteessa: www.etla.fi/julkaisuhaku.php Publications in pdf can be downloaded at www.etla.fi/eng/julkaisuhaku.php

\section{ETLA}

